\title{
Determination of Leisure Levels of Village Patronage UIN Sunan Kalijaga Yogyakarta: Improving Governance Patronage towards Rural Green Village and Environmentally Friendly
}

\author{
Supriatna $^{1}$, Thaqibul Fikri Niyartama ${ }^{2}$, and Iwan Kuswidi ${ }^{2}$ \\ ${ }^{1}$ Faculty of Sharia and Law, ${ }^{2}$ Faculty of Science and Technology, UIN Sunan Kalijaga, \\ Jl. Marsda Adisucipto No 1 Yogyakarta 55281, Indonesia. Tel. +62-274-540971, Fax. +62-274-519739 \\ Author correspondency ${ }^{1}$ : \\ soepriatna@yahoo.co.id
}

\begin{abstract}
This study took place in the village of Patronage UIN Sunan Kalidjaga Yogyakarta that consist of 13 hamlets (Klidon, Banjarsari, Wonosalam, Dongkelsari, Puntuk, Tanjung Sari, Karang Lo, Purworejo, Tanjung, Banturejo, Nglengkong and Surirejo), Sukoharjo Village, District Ngaglik, DIY Sleman regency. Data are collect and analysed in order to obtain results in a level of comfort. The analysis was performed by using a formula based on the comfort level Temperature Humidity Index (THI). The results showed that Hamlet Klidon, Banjarsari, Wonosalam, and Dongkelsari shows Not Comfortable, whereas Hamlet Puntuk, Tanjung Sari, Karang Lo, Purworejo, Tanjung, Banturejo, Nglengkong, Surirejo and Mujen show Strongly Comfortable mainly on the clock 10:00 to 15:00.
\end{abstract}

Keywords: Patronage village, Comfort Level, Temperature Humidity Index (THI).

\section{Introduction}

The village is basically an ideal residential location. This is because the cool environment filled with trees as a source of oxygen and water supplies are abundant. However, there is a negative impact on rural development which cannot be avoided that include changes in environmental quality. The change of the environmental quality of course have an impact on people and life. One of the changes is a decrease in the environmental quality of air quality including the change in climate parameters, especially temperature.

The impact of a decrease in air quality influenced the quality of the rural environment. This is because the human and natural environment cannot be separated, they interact and influence each other, including influenced the surrounding neighborhoods. Therefore, one of the factors to consider in choosing a dwelling is a neighborhood that has a good quality of aspects of climate and air temperature.

Climate is one of the biophysical components are taken into account in the framework of human adaptation to the natural environment, one of them in terms of choosing a dwelling. So it can be assumed that the climatic conditions both macro and micro affect the quality of neighborhoods. Changes in the amount of rainfall, air temperature, wind speed and humidity affect the quality criteria of a good village environment. This needs to be considered in the choice of residential location in order to achieve comfort in an activity for the entire population.

So far, studies have been conducted regarding the level of comfort (humidity index) in relation to the climatological factors, but most of these studies are not spatially or research areas include a point / block large areas. This is understandable, because the studies conducted terrestrial, which of course takes time and labor costs are great. Therefore, research in areas that are quite specific coverage is rarely done.

Actually, the development of remote sensing technology capable of overcoming the obstacles encountered by research conducted using terrestrial methods. The use of remote sensing data can be used to obtain information that is directly or indirectly related to comfort, then the information can be used to measure the comfort level of a region.

In this study, in order to determine the level of comfort in the village of Patronage Universitas Islam Negeri (UIN) Sunan Kalijaga necessary information relating to changes in the climate elements such as air temperature, relative humidity, and wind speed. Finally, this study is expected to provide information about the quality of the environment in the village of Patronage UIN Sunan Kalidjaga as a first step to designing governance of the village towards the village green and environmentally friendly.

\section{Tools}

The tools used in this study are:

1. Global Positioning System (GPS) is used to determine the location of the measurement and facilitate plotting the data on a map.

2. Thermo hygrometer used to measure air temperature and relative humidity. 


\section{Research Data}

The following data is taken during this study, the Village: Sukoharjo, District: Ngaglik, District: Sleman, Yogyakarta.

Table 1. Data of air temperature and humidity.

\begin{tabular}{llllll}
\hline No & Village & Time & Position & Air Temperature & Humidity \\
\hline 1 & Klidon & 10.29 & $-7.7041547,110.4261053$ & 33.6 & $46 \%$ \\
2 & Banjarsari & 10.40 & $-7.6975199,110.4247859$ & 32.8 & $49 \%$ \\
3 & Wonosalam & 10.46 & $-7.6937960,110.4280415$ & 33.9 & $46 \%$ \\
4 & Dongkelsari & 10.58 & $-7.6836879,110.4307653$ & 33.6 & $45 \%$ \\
5 & Puntuk & 11.10 & $-7.6886566,110.4313688$ & 38.1 & $36 \%$ \\
6 & Tanjung Sari & 11.23 & $-7.6968149,110.4332366$ & 35.6 & $41 \%$ \\
7 & Karang Lo & 11.36 & $-7.7006707,110.4361444$ & 39.4 & $35 \%$ \\
8 & Purworejo & 11.52 & $-7.7055966,110.4323726$ & 40.1 & $32 \%$ \\
9 & Tanjung & 12.42 & $-7.7050605,110.4396199$ & 40.4 & $33 \%$ \\
10 & Banturejo & 12.52 & $-7.7089683,110.4313996$ & 40.8 & $31 \%$ \\
11 & Nglengkong & 13.00 & $-7.7085144,110.4207388$ & 40.8 & $31 \%$ \\
12 & Surirejo & 13.12 & $-7.7189814,110.4244178$ & 42.1 & $30 \%$ \\
13 & Mujen & 13.25 & $-7.7189814,110.4210858$ & 40.4 & $32 \%$ \\
\hline
\end{tabular}

\section{Analysis}

THI value of each criterion comfort level residential areas in Table 2 .

Table 2. Criteria Temperature Humidity Index (THI).

\begin{tabular}{lll}
\hline No & Criteria THI & Comfort Level \\
\hline 1 & $<29$ & Comfortable \\
2 & $29-30.5$ & Uncomfortable \\
3 & $>30.5$ & Very uncomfortable \\
\hline
\end{tabular}

From Table 2 can be classified village built which area is comfortable, uncomfortable, and very uncomfortable. To facilitate the reading can be seen in Table 3 below.

Table 3. Level of Leisure Village Patronage UIN Sunan Kalijaga.

\begin{tabular}{llll}
\hline No & Village & THI & Comfort Level \\
\hline 1 & Klidon & 29.9712 & Uncomfortable \\
2 & Banjarsari & 29.4544 & Uncomfortable \\
3 & Wonosalam & 30.2388 & Uncomfortable \\
4 & Dongkelsari & 29.904 & Uncomfortable \\
5 & Puntuk & 33.2232 & Very uncomfortable \\
6 & Tanjung Sari & 31.3992 & Very uncomfortable \\
7 & Karang Lo & 34.278 & Very uncomfortable \\
8 & Purworejo & 34.6464 & Very uncomfortable \\
9 & Tanjung & 34.9864 & Very uncomfortable \\
10 & Banturejo & 35.1696 & Very uncomfortable \\
11 & Nglengkong & 35.1696 & Very uncomfortable \\
12 & Surirejo & 36.206 & Very uncomfortable \\
13 & Mujen & 34.9056 & Very uncomfortable \\
\hline
\end{tabular}




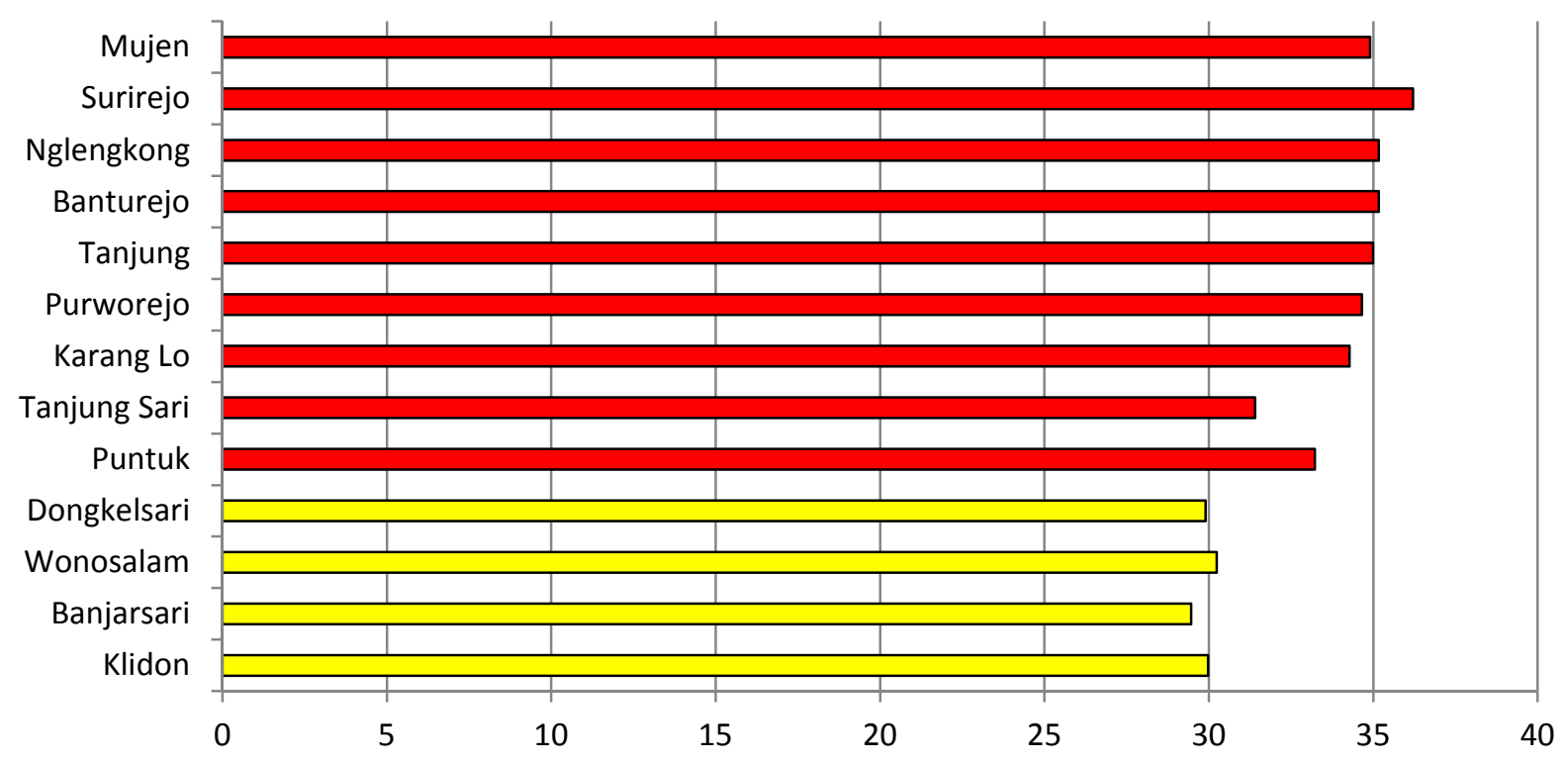

Description:

Horizontal axis : Temperature Humidity Index (THI)

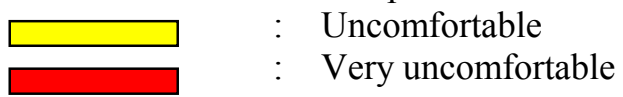

Figure 1. Level of Leisure Village Patronage UIN Sunan Kalijaga.

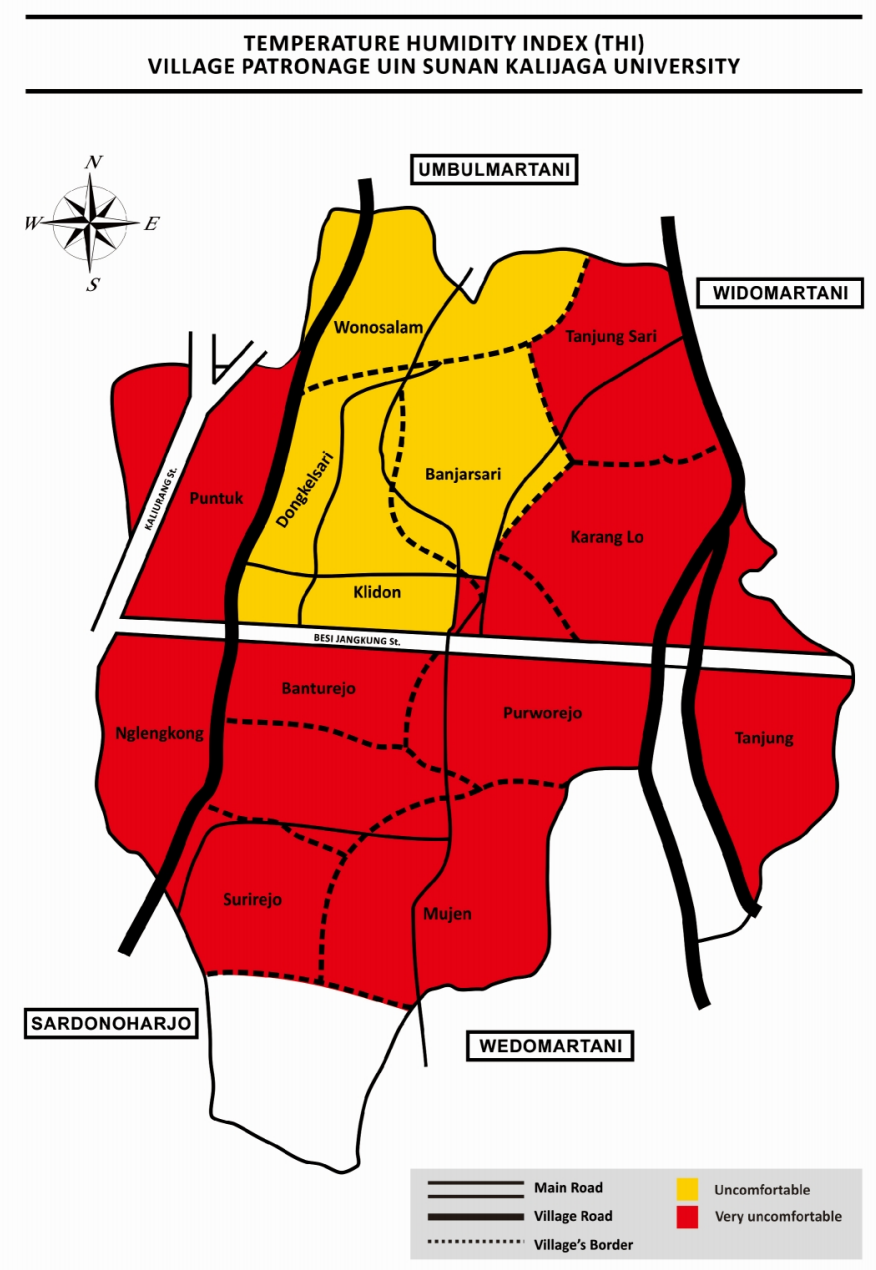

Figure 2. Temperature Humidity Index (THI) Village Patronage UIN Sunan Kalijaga. 
In Hamlet Klidon, Banjarasri, Wonosalam, and Dongkelsari the hours shown in Table 3 shows Not Comfortable, whereas Hamlet Puntuk, Tanjung Sari, Karang Lo, Purworejo, Tanjung, Banturejo, Nglengkong, Surirejo and Mujen the hours shown in Table 3 shows Strongly Comfortable. This is because the vegetation is not considered ole surrounding population.

\section{Conclusion}

Assuming that the Temperature humidity index (THI) is a real comfort level, it is necessary to increase the Patronage of vegetation in the village in an effort to increase the level of comfort in residential areas. This is seen in the results of the analysis. So the local community can feel comfort and also can improve the welfare of residents of the results of such vegetation.

\section{References}

Bintarto, R., S. Hadisumarmo, 1978, Metode Analisis Geografi, Yogyakarta: LP3ES.

Dewi, Anggraini., 1996, Penggunaan Foto Udara Dan Sistem Informasi Geografis (SIG) Untuk Mengkaji Kualitas Lingkungan Permukiman Dalam Hubungan Dengan Pola Penggunaan Air Minum (Air Domestik), Thesis-S1, Faculty of Geography, Universitas Gadjah Mada, Yogyakarta.

Ediyono, Setijati H., dkk, 1999, Prinsip-prinsip Lingkungan Dalam pembangunan Berkelanjutan, Direktorat Jenderal pendidikan Tinggi, Departemen Pendidikan dan Kebudayaan, Jakarta.

Indarto, Eddy, 1993, Pengaruh Suhu Udara Dan kelembaban Udara Terhadap Tingkat Ketidaknyamanan Fisiologis Penghuni Rumah tinggal Di Perumnas Banyumanik Semarang, Thesis-S2, Program Pasca Sarjana, Universitas Gadjah Mada, Yogyakarta.

Lillesand \& Kiefer, 1993, Penginderaan jauh Dan Interpretasi Citra, Yogyakarta: Gadjah Mada University Press.

Mather, J.R., 1974, Climatology: Fundamentals And Aplications, McGraw-Hill: New York.

Murdiyarso, D., S. Heny, 1992, Peranan Hutan Kota Dalam Pengendalian Iklim Kota, Seminar Sehari Iklim Perkotaan, Jakarta.

Pudjiastuti, L., R. Septa, R.S. Happy, 1998, Kualitas Udara Dalam Ruamg, Direktorat Jenderal Pendidikan Tinggi, Departemen Pendidikan Dan Kebudayaan.

Sulistyaningsih, Astin., 1995, Distribusi Suhu Udara Dan Faktorfaktor Lingkungan Yang Mempengaruhinya Serta Pengaruhnya Terhadap Curah Hujan Di Kotamadya Surakarta, Thesis-S1, Faculty of Geography, UGM, Yogyakarta.

Sutanto, 1986, Penginderaan jauh Jilid 1, Yogyakarta: Gadjah Mada University Press.

Sutanto, 1994, Penginderaan jauh Jilid 2, Yogyakarta: Gadjah Mada University Press.

Suwarsih, Kristianan, 1996, Evaluasi Kesehatan Lingkungan Permukiman Kota Berdasarkan Foto Udara Dan Sistem Informasi Geografis (SIG) Kasus Di Kecamatan Pasar Kliwon, Kotamadya Surakarta, Thesis-S1, Faculty of Geography, UGM, Yogyakarta.

Widyatmanti, Wirastuti, 1998, Pengaruh Perubahan Liputan lahan Terhadap Variasi Spasio Temporal Suhu Perkotaan Skala Mikro Dengan Bantuan Penginderaan jauh dan Sistem Informasi Geografis , Kasus Studi Di Daerah Semarang Utara, Thesis-S1, Faculty of Geography, UGM, Yogyakarta. 